\title{
Giant cell hepatitis associated with systemic lupus erythematosus
}

\author{
A Cairns, R F T McMahon
}

Department of Histopathology, Manchester Royal Infirmary, Oxford Road, Manchester M13 9WL

A Cairns

R F T McMahon

Department of

Pathological Sciences, Stopford Building,

University of

Manchester, Oxford

Road, Manchester

M13 9PT

R F T McMahon

Correspondence to: Dr A Cairns.

Accepted for publication 18 October 1995

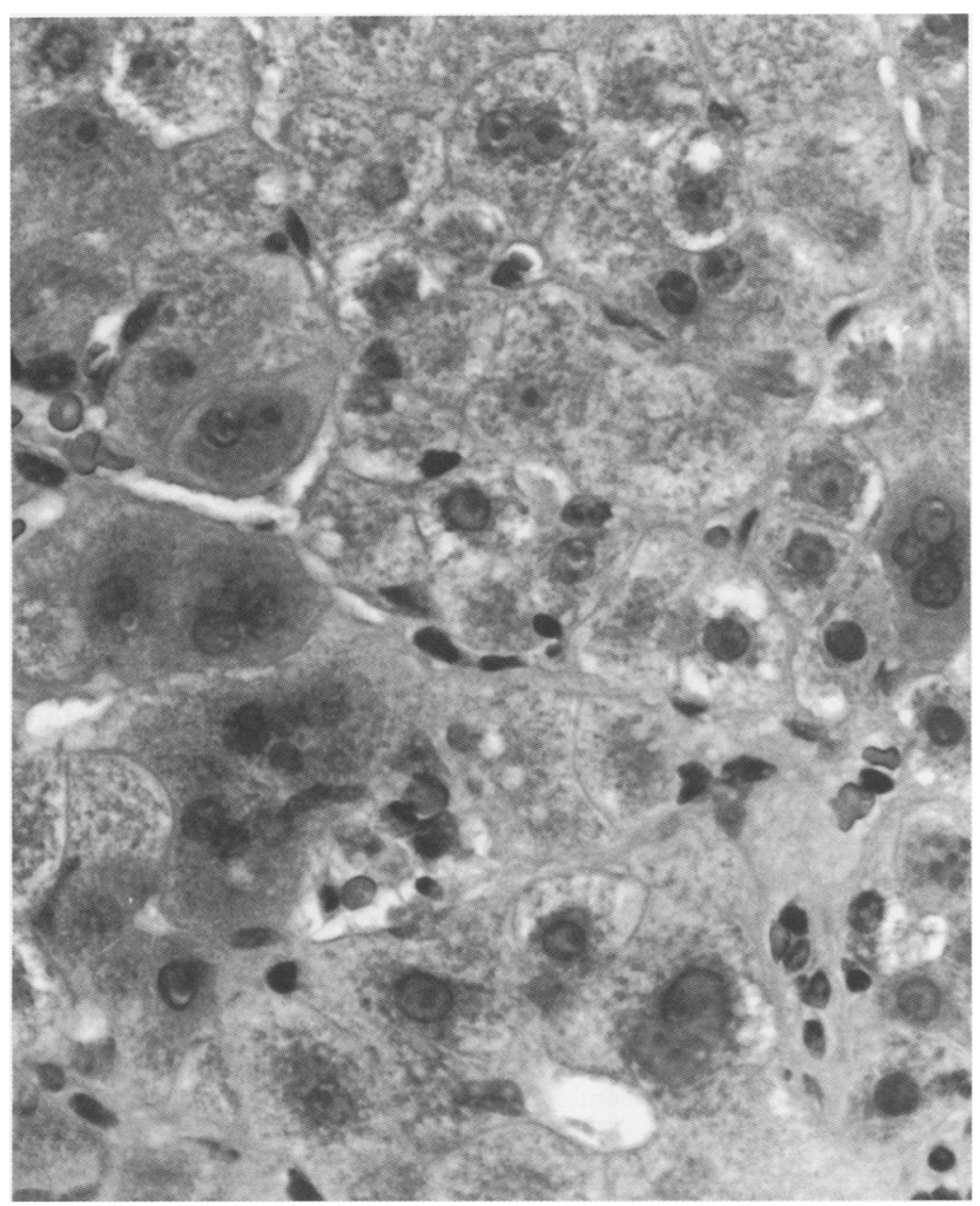

Periportal region with hepatocytes demonstrating giant cell transformation. made, the latter confirmed on biopsy of the sural nerve. Giant cells were noted on liver biopsy. The patient was treated with corticosteroids; liver function had improved after two years of follow up. When extensive giant cell transformation is noted on liver biopsy, particularly when neuropathy is also a feature, the possibility of an association with SLE should be considered.

(f Clin Pathol 1996;49:183-184)

Keywords: giant cells, hepatitis, systemic lupus erythematosus.

\section{Case report}

A 42 year old white woman presented with a five month history of paraesthesia and numbness of both the upper and lower limbs and with vague abdominal pain. Routine screening revealed raised liver function tests (aspartate aminotransferase (AST), $147 \mathrm{IU} / 1$; alanine aminotransferase (ALT), $149 \mathrm{IU} / 1$; alkaline phosphatase, $395 \mathrm{IU} / 1$; bilirubin, $37 \mu \mathrm{mol} / 1 ; \gamma-$ glutamyltransferase $(\gamma \mathrm{GT}), 217 \mathrm{IU} / \mathrm{l})$. Ultrasound scan of the abdomen showed gallstones; barium enema, endoscopic retrograde cholangiopancreatography and computed tomography scan were all normal. IgG antibodies to double stranded DNA were present at a titre of 40 units. Anti-cardiolipin antibodies, antimitochondrial antibodies and rheumatoid factor were not detected. Serology for hepatitis A, $\mathrm{B}, \mathrm{C}$, and paramyxoviruses was negative, as was the Paul Bunnell test. A clinical diagnosis of systemic lupus erythematosus (SLE) with an axonal sensory polyneuropathy was made, the latter confirmed on biopsy of the sural nerve.

Examination of a liver biopsy specimen revealed nodularity with portocentral septum formation, not amounting to cirrhosis. The most striking feature was the extensive giant cell transformation of hepatocytes, occurring predominantly in periportal/periseptal regions (figure). Portal tracts were expanded by a predominantly lymphocytic infiltrate and there was extensive irregular periportal and periseptal piecemeal necrosis with marked ductular proliferation. Hydropic swelling and a noticeable accumulation of copper associated protein within hepatocytes, especially the multinucleated variety, were noted. No viral nucleocapsids could be identified on electron microscopy.

The patient was treated with corticosteroids. Follow up at two years revealed an improvement in liver function (AST, $50 \mathrm{IU} / \mathrm{l}$; ALT, $58 \mathrm{IU} / \mathrm{l}$; alkaline phosphatase, $334 \mathrm{IU} / \mathrm{l}$; 
bilirubin, $10 \mu \mathrm{mol} / \mathrm{l} ; \gamma \mathrm{GT}, 270 \mathrm{IU} / \mathrm{l})$. The polyneuropathy was relatively quiescent. A second liver biopsy specimen demonstrated a reduction in giant cell transformation, but inflammation and fibrosis, not amounting to cirrhosis, were still present.

\section{Discussion}

Giant cells are present frequently in neonatal liver disease, but are rarely found after infancy. Post-infantile giant cell hepatitis refers to hepatitis associated with extensive giant cell change in the adult liver. It is a purely descriptive term, encompassing a heterologous group of disorders in terms of clinical, serological and histological features. ${ }^{1}$

Aetiological factors implicated include drugs (methotrexate, 6-mercaptopurine and clonmetacin), viruses (hepatitis A, B and C, Epstein-Barr virus and paramyxoviruses) and autoimmune chronic hepatitis. ${ }^{1}$ Devaney et $a l^{2}$ found evidence of autoimmune disease (positive antinuclear antibody or direct Coombs reaction and anaemia) in $40 \%$ of patients.

About $8-23 \%$ of patients with SLE develop liver disease, which is usually of modest clinical relevance and occurs in patients with a higher frequency of positive DNA antibody of double stranded type. ${ }^{3}$ Liver biopsy diagnoses have included granulomatous hepatitis, cirrhosis, chronic active hepatitis, chronic persistent hepatitis, and steatosis. ${ }^{4}$

Giant cell hepatitis has been reported in association with neonatal SLE ${ }^{5}$ and, more recently, with SLE in an adult. ${ }^{6}$ The first two cases of giant cell hepatitis in association with neurological features have also been published recently. ${ }^{1}$ The current case shares similarities in that the patient presented with neurological features and abnormal liver function tests were detected only on routine screening. This suggests that when extensive giant cell transformation is noted on liver biopsy, particularly when neuropathy is also a feature, the possibility of an association with SLE should be considered.

We thank Drs RM Bernstein, JM Braganza and W Schady for permission to report this case.

1 Johnson SJ, Mathew J, MacSween RMN, Bennett MK, Burt AD Adult giant cell hepatitis: Histological and im AD. Adult giant cell hepatitis: Histological and im 2 Devaney K, Goodman ZD, Ishak KG. Post infantile giant cell transformation in hepatitis. Hepatology 1992;16:327-33. 3 Caramaschi P, Biasi D, Botto M, Carletto A, Manzo T, Bambara LM. Interessamento epatico nel lupus eritematoso sistemico. Recenti Prog Med 1993;84:673-8.

4 Runyon BA, LaBrecque DR, Anuras S. The spectrum of liver disease in systemic lupus erythematosus. Report of 3 histolorically-proved cases and review of the literature. $A m$ histologically-proved cas

5 Evans $N$, Gaskin $\mathrm{K}$. Liver disease in association with neonatal lupus erythematosus. F Paediatr Child Health 1993;29:478-80. 6 Dohmen K, Ohtsuka S, Nakamura H, Arase K, Yokogawa Y, Asayama R, et al. Post-infantile giant cell hepatitis in an elderly female patient with systemic lupus erythematosus. f Gastroenterol 1994;29:362-8.

\title{
Chaetomium pneumonia in patient with acute myeloid leukaemia
}

\author{
T Yeghen, L Fenelon, C K Campbell, D W Warnock, A V Hoffbrand, H G Prentice, \\ C C Kibbler
}

Department of Microbiology, Royal Free Hospital, Pond Street, Hampstead, London NW3 2 QG

$\mathrm{T}$ Yeghen

C C Kibbler

Department of

Haematology

A V Hoffbrand

H G Prentice

Mycology Reference Laboratory, Myrtle Road, Kingsdown,

Bristol BS2 8EL

C K Campbell

D W Warnock

Department of Microbiology,

St Vincent's Hospital, Elm Park, Dublin 4, Ireland

L Fenelon

Correspondence to: Dr T Yeghen.

Accepted for publication 18 October 1995

\begin{abstract}
A patient with relapsed refractory acute myeloid leukaemia developed typical fungal lung lesions despite intravenous amphotericin B prophylaxis. Chaetomium globosum was cultured from the resected right lower lobe. Histology showed branching hyphae negative for common Aspergillus species by immunohistochemical staining. Previous reports of invasive disease caused by Chaetomium and some applications of immunohistochemical staining for Aspergillus are discussed. (f Clin Pathol 1996;49:184-186)
\end{abstract}

Keywords: Chaetomium globosum, pneumonia, immunohistochemical staining, Aspergillus.

Patients with haematological malignancies are susceptible to invasive fungal infections. Although the great majority of such infections are caused by Aspergillus or Candida species, various fungi of low pathogenicity have oc- casionally been reported to cause invasive disease in these immunosuppressed patients.

Because invasive fungal infections are common and devastating complications of cytotoxic therapy in this group of patients, treatment with intravenous amphotericin B is usually introduced within 96 hours of onset of a fever resistant to broad spectrum antibiotics and for which no cause has been determined, or as soon as lesions raising the suspicion of invasive fungal infection (IFI) appear. For those patients undergoing surgical resections as part of the treatment of mycotic lung sequestra (MLS), systemic amphotericin B may already have been given for several days before the operation and, in our institution, fungi are frequently not isolated from the operative sample, so that the only evidence of IFI is the presence of fungal elements on tissue sections.

These hyphae tend to be identified as those of Aspergillus species by default even when not entirely typical. Under such circumstances there is no routine method for proving that the 